\title{
Northern Alberta Health Libraries Association (NAHLA) News
}

\section{6 / 2007 NAHLA Executive}

The NAHLA Annual General Meeting was held on September 26, 2006. The membership voted in the following new officers for the year:

- $\quad$ Liz Dennett, President

- Orvie Dingwall, Vice-President

- Liza Chan, Past President

- Linda Seale, Treasurer

- Connie Winther, Secretary

\section{Events}

In early November, NAHLA hosted the Medical Library Association's Webcast, Moving at the Speed of Byte: Emerging Technologies for Information Management. The goal of the session was to expose information professionals to new and emerging technologies and to encourage their use in information management.

At the end of November, NAHLA hosted a Leading Edge Workshop, EBSCO-CINAHL with Linda Slater (Nursing Liaison Librarian, JW Scott Health Sciences Library, University of Alberta), presenting the new EBSCO version of the CINAHL database.

Two Leading Edge Workshops are planned for 2007. The first, Evaluating systematic reviews, presented by Jeanette Buckingham (Medicine Liaison Librarian, JW Scott Health Sciences Library, University of Alberta), will focus on how to evaluate systematic reviews. The second will focus on consumer health websites and will include presentations by NAHLA members about the top ten sites as identified by the Consumer Health Information Providers Groups (CHIPIG).

The final event being planned for the year is a conference jointly hosted and sponsored by NAHLA, the Southern Alberta Health Libraries Association (SAHLA) and the Health Knowledge Network (HKN). This conference will amalgamate NAHLA's annual spring TRENDS Mini-Conference and the HKN Annual Symposium in an attempt to reach a wider audience and to allow the chapters an opportunity to work together. The theme of the conference is Complementary and Alternative Medicine and is scheduled to be held in Calgary in November 2007.

\section{NAHLA History Project}

The purpose of the NAHLA History project is to capture, collect and document the history and activities of NAHLA; record and share the process with other Chapters; and systematically organize NAHLA documents for delivery to the Provincial Archives of Alberta, where they will be available for research and study. The group consists of six 
NAHLA members and is chaired by Marlene Dorgan (Head, JW Scott Health Sciences Library, University of Alberta). The group will present a poster and fact sheet at the Canadian Health Libraries Association Conference in Ottawa, in May 2007. 